„Studia Wyborcze”, tom 27, 2019

DOI: https://doi.org/10.26485/SW/2019/27/6

\title{
Maciej Rakowski*
}

\section{HAWAJSKIE PRAWODAWSTWO WYBORCZE W LATACH 1840-1864}

\section{UWAGI WSTĘPNE}

Gdy w 1778 roku ekspedycja Jamesa Cooka dotarła na Hawaje, na wyspach archipelagu istniało kilka niezależnych monarchii. Na początku XIX wieku zjednoczył je Kamehameha I, który w 1810 roku ogłosił powstanie Królestwa Hawajów. Stworzone przezeń państwo było monarchią absolutną do 1840 roku, gdy Kamehameha III ogłosił pierwszą ustawę zasadniczą. Do tego czasu nie istniał na wyspach parlament, nie było więc również prawa wyborczego określającego zasady wyłaniania deputowanych (na temat dziejów Hawajów do lat 60. XIX w. zob.: Kuykendall 1938: 1-428; Kuykendall 1953: 1-134; Kuykendall, Grove Day: 1-137; Daws 1968: 1-190; Siler 2012: 1-37; Haley: 1-207).

Po wpisaniu do ustawy zasadniczej istnienia organu przedstawicielskiego hawajskie elity stanęły przed koniecznością uregulowania zasad wybierania deputowanych. Dla wyspiarskich prawodawców była to problematyka całkowicie nowa, choć i na tym polu mogli korzystać z pomocy białych doradców. Warto zbadać, jak Hawajczycy poradzili sobie z niełatwym zadaniem stworzenia ordynacji wyborczej, pamiętać przy tym należy, że układano wówczas przepisy dla ludzi, którzy dotąd nie słyszeli o konstytucji, parlamencie oraz mandacie poselskim. Początki hawajskiego prawa wyborczego to zagadnienie naukowo w zasadzie nieopracowane. Badacze dziejów archipelagu, nie wchodząc w analizę aktów prawnych, ograniczają się do przywołania jedynie podstawowych informacji o regułach wyłaniania reprezentantów. Przedmiotowe opracowanie

* Dr hab., prof. UŁ, Zakład Badań nad Rozwojem Administracji i Prawa, Wydział Prawa i Administracji, Uniwersytet Łódzki, mrakowski@wpia.uni.lodz.pl, ORCID: 0000-0001-7378-9311. 
ma zatem wypełnić lukę w badaniach jednocześnie otwierając drogę do późniejszych rozważań o charakterze porównawczym.

Przedstawiamy początkowy okres rozwoju hawajskiego prawa wyborczego przypadający na lata 1840-1864. Jego koniec wiązać należy z wejściem w życie trzeciej z kolei ustawy zasadniczej, która przyniosła istotną zmianę prawa wyborczego polegającą na wprowadzeniu cenzusu majątkowego. Zajmujemy się regulacją zasad wyłaniania deputowanych w dwóch pierwszych konstytucjach oraz w ordynacjach wyborczych z 1842 oraz 1850 roku. Analizujemy przede wszystkim przesłanki nabywania prawa głosu oraz prawa wybieralności, a także zasady rozdziału mandatów poselskich. Nie pomijamy jednak również zagadnień związanych z organizacją i przebiegiem głosowania, zwłaszcza rozwiązań najbardziej oryginalnych, przesądzających o wyjątkowości hawajskiego prawa wyborczego.

Instytucje hawajskiego prawa wyborczego prezentowane są w układzie chronologicznym, dzięki któremu lepiej dostrzegalna jest ewolucja przyjmowanych na wyspach rozwiązań, w tym na przykład relacje między przepisami o prawie głosu a prawem wybieralności w danym akcie prawnym.

\section{PRAWO WYBORCZE W KONSTYTUCJI Z 1840 ROKU I ORDYNACJI Z 1842 ROKU}

Konstytucja z 1840 roku $^{1}$ przewidywała, że władzę ustawodawczą sprawować będzie dwuizbowy parlament (The Legislative Body), zbiegający się na corocznej sesji. Składał się z House of Nobles, czyli Izby Szlachty, oraz The Representative Body - Izby Reprezentantów. Członków pierwszego z tych organów, czyli izby wyższej, mianował władca. Deputowani byli wybierani na roczną kadencję przez ludność wysp (przy czym wyraźnie wskazano tylko cztery największe: Hawaii, Maui, Oahu i Kauai) [Kuykendall 1938: 169; Kukendall 1940: 12; Chambers 1896: 13]. W ustawie zasadniczej nie określono liczby reprezentantów, ani zasad ich wybierania, uregulowano to dopiero w edykcie z 1840 roku

Pierwszy akt określający zasady wyborów został uchwalony przez parlament 2 listopada 1840 roku Nosił tytuł Of the Representative Body ${ }^{2}$, składał się

1 The first constitution of Hawaii, [Lydecker 1918: 8-15]; zob. też: http://hooilina.org/collect/ journal/index/assoc/HASH0166.dir/5.pdf (dostęp 1.03.2019). Nie wskazujemy oznaczeń przepisów tej konstytucji, bowiem nie zostały one wyodrębnione (akt dzielił się jedynie na rozdziały).

${ }^{2}$ Korzystaliśmy z tekstu opublikowanego w zbiorze aktów prawnych wydanym w $1842 \mathrm{r}$., w którym został oznaczony jako rozdział drugi następującej po konstytucji z 1840 r. części oznaczonej tytułem Laws of the Hawaiian Islands - Chapter II, w: Translation of the constitution 
z zaledwie pięciu artykułów. W treści dokumentu określono go mianem edyktu (a nie ustawy), zaś w ostatnim akapicie wskazano, że został przyjęty przez Izbę Szlachty, bez wzmianki o izbie niższej. Podobne informacje znajdujemy w treści innych aktów z 1840 roku, co pozwala na sformułowanie wniosku, że przed wyborem reprezentantów jako parlament działali sami nobles. Edykt został podpisany przez króla Kamehamehę III oraz królową wdowę Kekāuluohi, pełniącą urząd kuhina-nui, będący funkcją pośrednią między wicekrólem a premierem [Kuykandall, Grove Day 1976: 54, 140]3.

W akapicie wstępnym prawodawca wskazał, że określa zasady wyboru osób, które - zgodnie z konstytucją - miały zasiadać w parlamencie wraz z Nobles. Jednocześnie zapowiedziano zwiększenie liczby posłów w przyszłości. W art. 1 rozdzielono mandaty w izbie niższej - po dwóch deputowanych miało być wybieranych na wyspach Hawaii, Oahu oraz Maui (wraz z przyległymi mniejszymi wyspami), zaś na Kauai - jeden.

W art. 2 edyktu opisano zasady wyłaniania reprezentantów, przy czym uczyniono to w odniesieniu do wyspy Hawaii, stanowiąc w końcowej części artykułu, że jego przepisy odnosiły się do pozostałych wysp (choć nie wszędzie wybierano dwóch reprezentantów). Każdy z mieszkańców wyspy mógł skierować do monarchy list, w którym wskazywał nazwiska „dwóch mądrych osób” (two persons of wisdom, określanych dalej jako men of wisdom i prudence), które w ten sposób wskazywał jako preferowanych kandydatów do legislatywy. Prawodawca przedstawił formularz pisma do króla (wskazanego z imienia, czyli do Kamehamehy), w którym należało wpisać nazwiska pierwszego i drugiego preferowanego kandydata oraz złożyć podpis. Pisemny głos nie musiał pochodzić od jednej tylko osoby. W omawianym przepisie wskazano, że list mógł krążyć wśród poddanych i każdy zainteresowany mógł pod nim złożyć podpis. Nazwiska osób, które w ten sposób oddały głosy miały zostać zliczone, a wybrane miały zostać osoby „mające większość”. Użyte przez ustawodawcę słowo majority oznaczało - naszym zdaniem - największą liczbę głosów, nie zaś większość bezwzględną.

Z brzmienia art. 4 zdaje się wynikać, że to władca osobiście zajmować się miał liczeniem oddanych głosów. Czytamy bowiem, że gdy tylko „Jego Wysokość ustalił nazwiska wybranych osób", premier miał poinformować je o wyborze oraz o dacie i miejscu zebrania legislatury. Oczywiście, to nie król

and laws of the Hawaiian Islands, established in the reign of Kamehameha III, Lahainaluna 1842, s. 22-23. Błędnie - gdyż na 1842 r. - omawiany edykt datuje R.C. Schmitt, kierując się zapewne datą wydania zbioru, a nie wskazaną w tekście edyktu datą jego uchwalenia [Schmitt 1971: 50].

${ }^{3}$ Na temat urzędu kuhina nui - zob. Kobus [2017: 38-41].

${ }^{4}$ Omawiany tryb wyborów w zarysie przedstawiono w literaturze R. Kuykendall [1938: 227-228]; R.C. Schmitt [1971: 50]. 
zajmował się liczeniem głosów, w omawianym akcie nie zajęto się jednak kwestią organów przeprowadzających wybory. Zakładać zatem można, że władca miał swobodę wyznaczenia osób, do których należało zebranie i odczytanie głosów oraz ustalenie wyników głosowania.

\section{USTAWY Z 1850 ROKU}

Bardziej kompleksowa regulacja prawa wyborczego nastąpiła dopiero dziesięć lat po powstaniu hawajskiej legislatywy. W dniu 30 lipca 1850 roku parlament uchwalił dwie ustawy: o uregulowaniu wyborów reprezentantów ludu (dalej: u.u.w.) oraz o zwiększeniu liczby reprezentantów ludu w ciele usta-

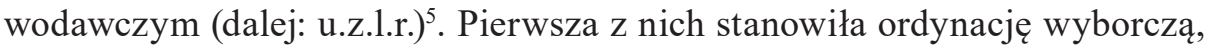
niezbyt obszerną, bowiem złożoną jedynie z osiemnastu artykułów. Druga zawierała dwa przepisy dotyczące prawa wyborczego (określające liczbę deputowanych i podział na okręgi oraz zasady nabywania biernego prawa wyborczego), a także artykuły odnoszące się do diet poselskich, przysięgi składanej przez deputowanych, publicznego charakteru obrad legislatywy oraz uprawnienia ministrów do zasiadania w izbie wyższej.

Czynne prawo wyborcze opisano w art. 11 u.u.w. Prawo głosu przysługiwało mężczyznom będącym poddanymi hawajskiego władcy, zarówno tubylcom, jak i naturalizowanym cudzoziemcom ${ }^{6}$. Cenzus wieku określono na poziomie 20 lat. Przewidziano także wymóg domicylu - prawo głosu było uzależnione od zamieszkiwania na wyspach w ciągu roku bezpośrednio poprzedzającego dzień wyborów ${ }^{7}$. Czynnego prawa wyborczego pozbawione były osoby dotknięte chorobą psychiczną (insane) oraz skazane kiedykolwiek za hańbiącą zbrodnię (infamous crime), chyba że zostały ułaskawione przez władcę ${ }^{8}$.

${ }^{5}$ An act to regulate the election of representatives of the people oraz An act to increase the number of the representatives of the people in the Legislative Council, [w:] Penal code of the Hawaiian Islands, passed by the House of Nobles and Representatives on the $21^{\text {st }}$ of June, A. D. 1850; to which are appended the other acts passed by the House of Nobles and Representatives during their general session for 1850, Honolulu 1850, s. 161-167. Opieraliśmy się na angielskiej wersji aktu, choć w połowie stulecia teksty ustaw sporządzano w języku hawajskim. Jednak ich tłumaczenie na język angielski miało walor niemal tekstu urzędowego.

${ }^{6}$ Obok naturalizowanych cudzoziemców prawodawca wymienił również kategorię określoną mianem denizens, oznaczającą cudzoziemców, którzy zostali przez władcę zrównani w prawach z tubylcami [Schmitt 1971: 57].

7 Przepis o domicylu nie był jasny. Mowa w nim była o these islands, mogło więc chodzić o roczne zamieszkanie w Królestwie, ale nie można wykluczyć, że konieczny był odpowiednio długi pobyt na wyspie, na której miało być wykonywane prawo głosu, tym bardziej, że dalej wskazano, iż wyborca miał jeden głos w dystrykcie, w którym zamieszkiwał.

${ }^{8}$ Na temat czynnego prawa wyborczego zob. R. Kuykendall [1938: 265]; J.L. Haley [2014: 141]. 
Dość osobliwie uregulowano tryb weryfikacji posiadania prawa głosu. Zgodnie z art. 12 tej samej ustawy każdy z inspektorów wyborczych lub wyborców uprawnionych do głosu w tej samej komisji mógł zakwestionować posiadanie prawa głosu przez daną osobę. Sprawę rozstrzygała wówczas komisja inspektorów wyborczych na podstawie przysięgi złożonej przez zainteresowanego, w której miał on potwierdzić posiadanie wymaganych prawem kwalifikacji (art. 13 u.u.w.). Odmowa złożenia przysięgi skutkowała niedopuszczeniem do głosowania (art. 14 u.u.w.).

Zasady korzystania z biernego prawa wyborczego określone zostały w art. 2 u.z.1.r. Prawo wybieralności przysługiwało: mężczyznom, poddanym hawajskiego władcy oraz naturalizowanym cudzoziemcom (denizens), w wieku ukończonych lat 25, umiejącym czytać i pisać, rozumiejącym rachunki, zamieszkałym w królestwie od przynajmniej roku, którzy nie byli oskarżeni o jakąkolwiek zbrodnię lub występek. Cenzus wykształcenia został opisany w sposób rażąco ogólnikowy. Prawodawca nie wskazał, kto i jak miał weryfikować zdolność czytania, pisania i rachowania. Samo zresztą pojęcie „rozumienia rachunków" (to understand accounts) było wyjątkowo nieprecyzyjne. Zestawienie przepisów o czynnym i biernym prawie wyborczym prowadzi do zaskakującego wniosku, że osoba karana nie mogła głosować, ale mogła za to ubiegać się o wybór do parlamentu (o ile nie toczyło się wobec niej kolejne postępowanie karne).

System wyborczy był prosty: zastosowano jednomandatowe okręgi (z wyjątkiem stolicy, o czym niżej), a o wyborze decydowała względna większość głosów. Podział kraju na okręgi wynikał z art. 1 u.z.l.r. Wskazano w nim, ilu przedstawicieli miało być wybieranych na każdej z wysp, a jeśli liczba ta była większa od jednego, wyliczono dystrykty i mniejsze jednostki podziału administracyjnego, z których miał być wybierany jeden poseł. Dla przykładu można przywołać regulację dotyczącą wyspy Maui, z której miało pochodzić pięciu reprezentantów. Ustawodawca wskazał, że mandaty rozdzielono w sposób następujący: ,,jeden dla dystryktu Lahaina, Oloalu, Ukumehame i Kahoolawe, jeden dla dystryktu Kohakuloa oraz Kaanapali, jeden od Waihee do Honuaula', jeden od Kahihinui do Koolau, jeden od Hamakualoa do Kula". Jedyny wyjątek uczyniono dla stołecznego Honolulu, któremu przypadły dwa mandaty, przy czym użyte przez prawodawcę sformułowanie (Two from Maunalua to Moanalua) nie przesądza, czy miały tam powstać dwa okręgi jednomandatowe, czy jeden dwumandatowy. Ta druga możliwość wydaje się znacznie bardziej prawdopodobna; także w piśmiennictwie odnajdujemy informację o 22 jednomandatowych okręgach oraz jednym większym w stolicy [Schmitt 1971: 50].

\footnotetext{
${ }^{9}$ Dosłownie: One from Waihee to Honuaula.
} 
W aktach z 1850 roku nie wskazano wyraźnie, że mandat miał przypaść kandydatowi, który uzyskał najwięcej głosów, nie ma jednak wątpliwości, iż taka była podstawowa zasada ówczesnego hawajskiego systemu wyborczego. Przy jednomandatowych okręgach fotel deputowanego siłą rzeczy musi przypaść zwycięzcy głosowania, różnice wynikać mogą tylko z ewentualnego istnienia drugiej tury wyborów. Ponieważ w analizowanych ustawach nie znajdujemy wzmianki o drugiej turze głosowania, za oczywiste uznajemy, że wybór miał nastąpić już w pierwszym głosowaniu. To z kolei prowadzi do wniosku, że mandat przypadał kandydatowi z największą liczbą głosów, niezależnie od tego, czy udało mu się zgromadzić połowę głosów oddanych w okręgu. Wniosek ten znajduje potwierdzenie w treści art. 9 u.u.w., w którym wskazano, że po zliczeniu głosów inspektorzy ogłosić mieli, który z kandydatów uzyskał największą liczbę głosów. W tym samym przepisie czytamy, że kandydat ten miał od inspektorów otrzymać zaświadczenie (certificate) o brzmieniu ustalonym przez prawodawcę. Miało z niego wprost wynikać, że dana osoba została wybrana reprezentantem określonego dystryktu; należało też wskazać, o ile głosów więcej od któregokolwiek z konkurentów uzyskał zwycięzca wyborów.

Podstawowym organem hawajskiej administracji wyborczej miała być rada inspektorów (a board of inspectors), której zadaniem miało być przeprowadzenie wyborów oraz decydowanie o uprawnieniu do głosowania. W składzie rady mieli się znaleźć sędziowie okręgowi (district justices - sędziowie najniższej instancji, odpowiednik sędziów pokoju), poborca podatkowy (tax collector) i inspektor szkolny (the school inspector of the district). Osoby wskazane przez ustawodawcę mogły delegować do rady swoich zastępców. Przewodniczącym rady był sędzia okręgowy o najdłuższym stażu (art. 2 u.u.w.). Rada inspektorów dla każdego z dystryktów miała wyznaczyć i zaprzysiąc jednego lub więcej urzędników (clerks). Jako ich zadanie wskazano tylko odnotowywanie nazwisk osób oddających głosów (art. 2 u.u.w.).

Przepisy określające przebieg głosowania były dość lakoniczne. Głosowanie odbywało się w całym kraju w pierwszy poniedziałek stycznia każdego roku, w miejscach wyznaczonych przez szeryfów (sheriffs) wysp (art. 1 u.u.w.). Lokale wyborcze (the polls) miały być otwarte od godziny 8 do 17 (art. 4 u.u.w.). Wyborca miał oddawać głos na karcie wyborczej (ballot). Nie przewidziano jednak kart przygotowanych przez administrację wyborczą, ale głosujący miał przybyć $\mathrm{z}$ własną kartą, złożoną w sposób ukrywający jej zawartość. Karta miała być wręczana jednemu z inspektorów w obecności pozostałych (art. 4 u.u.w.). Takie sformułowanie zdawało się przesądzać, że głosowanie było prowadzone przez radę inspektorów, co z kolei oznaczało, że w okręgu mógł działać tylko jeden lokal wyborczy. Otrzymaną kartę inspektor niezwłocznie umieszczał w urnie (box); karty nie mogły być wyjmowane do chwili obliczania głosów (art. 7 u.u.w.). 
W art. 5 u.u.w. dookreślono, jak miała wyglądać karta dostarczana przez głosującego. Miała to być kartka papieru (paper ticket), na której zapisano lub wydrukowano (lub nawet częściowo wydrukowano, a częściowo napisano) „nazwisko lub nazwiska osoby lub osób na które wyborca głosuje”. Tak sformułowany przepis trudno zinterpretować. W sytuacji, gdy w okręgu wybierano jednego tylko posła, oczywiste wydaje się, że wyborca dysponował jednym głosem. Tymczasem hawajski prawodawca upoważnił wyborcę do oddania większej liczby głosów, nie wskazując nawet ilu maksymalnie. Nie określono też, jak przy obliczaniu głosów należało traktować nazwiska zapisane na karcie. $\mathrm{W}$ art. 8 u.u.w. czytamy jedynie, że po zamknięciu głosowania bez nieuzasadnionej zwłoki inspektorzy mieli przystąpić do obliczania głosów oddanych na poszczególnych kandydatów. Co ciekawe, przy obliczaniu głosów mógł być obecny każdy zainteresowany.

Mimo że w wyżej przywołanym art. 8 u.u.w. prawodawca posłużył się pojęciem „kandydaci” (candidates), to nic nie wskazuje na to, by istniała urzędowa rejestracja kandydatów przed dniem wyborów. Nie było też takiej konieczności, gdyż nie istniały urzędowe karty wyborcze. Dopiero po ustaleniu, kto uzyskał najwięcej głosów, pojawiał się problem, czy osoba ta spełniała warunki wybieralności.

W ordynacji wyborczej przewidziano również możliwość kwestionowania wyniku wyborów oraz odpowiedzialność za bezprawne wpływanie na ten wynik. Przynajmniej pięćdziesięciu wyborców mogło zwrócić się do parlamentu z petycją, w której zarzucali, że wybór nastąpił w wyniku przekupstwa, innych nieuczciwych działań (other unfair means) albo wybrany nie spełnia warunków wybieralności. Wówczas parlament ${ }^{10}$ miał zbadać sprawę, a jeśli zarzuty okazały się uzasadnione, natychmiast ogłaszał nieważność kwestionowanego wyboru. W takim przypadku czynności wyborcze miały zostać powtórzone (art. 10 u.u.w.).

Hawajski prawodawca przewidział prawnokarną ochronę prawidłowości wyborów. Sprawca, który przekupując inną osobę pieniędzmi, obietnicą lub nagrodą, bądź używając wobec niej gróźb, nakłonił ją do głosowania na określoną osobę, podlegał karze grzywny w kwocie 50 dolarów. Karę wymierzyć miała policja lub sędzia okręgowy, a przychody z kar miały być przeznaczone na utrzymanie szkół (art. 17 u.u.w.). Szczególnej odpowiedzialności miały podlegać osoby działające jako inspektorzy wyborczy. Jeśli przed gubernatorem wyspy udowodniono, że dopuścili się oszustwa lub innego nieuczciwego postępowania w związku z wyborami, mieli natychmiast utracić pełnioną funkcję i przez pięć lat nie mogli sprawować żadnego urzędu podległego rządowi (art. 16 u.u.w.).

${ }^{10}$ Nie sprecyzowano, czy tylko izba niższa, czy obie izby. 
W art. 18 u.u.w. wskazano, że za wykonanie przepisów ordynacji odpowiedzialny miał być minister spraw wewnętrznych. Zapowiedziano opublikowanie tekstu ustawy w gazetach „Elele” i „Polynesian”, a także w postaci odrębnych wydawnictw, które miały „krążyć po kraju” - pięciuset kopii w języku hawajskim, stu po angielsku.

\section{PRAWO WYBORCZE W KONSTYTUCJI Z 1852 ROKU}

W 1852 roku została uchwalona druga hawajska konstytucja ${ }^{11}$, z punktu widzenia techniki prawodawczej znacznie doskonalsza od pierwszej. Utrzymano w niej zasadę dwuizbowości parlamentu, wciąż złożonego z obsadzanej przez władcę Izby Szlachty oraz Izby Reprezentantów (art. 60), której członków wybierano na roczną kadencję (art. 75). Odtąd zasady wyboru posłów określono w ustawie zasadniczej, podobnie liczbę reprezentantów, których miało być nie mniej niż 24 i nie więcej niż 40 (art. 75) [Kuykendall 1938: 268; 1940: 39; Alexander 1891: 272; Chambers 1896: 19]. Sprecyzowanie ich liczby oraz dokonanie rozdziału mandatów pomiędzy wyspy należało do legislatury, która miała tego dokonać z zachowaniem zasady równości, czyli w związku z liczbą ludności ustaloną podczas urzędowego spisu (art. 76).

W ustawie zasadniczej z 1852 roku zagwarantowano demokratyczny charakter wyborów, przede wszystkim ich powszechność. Czynne prawo wyborcze posiadali mężczyźni (rodowici Hawajczycy lub naturalizowani cudzoziemcy), którzy osiągnęli wiek 20 lat i przebywali w królestwie przez okres jednego roku bezpośrednio poprzedzającego termin wyborów (art. 78). W tym samym przepisie znalazło się zastrzeżenie, że wyborcą jest ten, „,kto opłaca swoje podatki” - who shall have paid his taxes [McKenzie 1991: 10]. Ustrojodawca nie wskazał żadnych kwot ciężarów publicznych, dlatego - naszym zdaniem - nie był to klasyczny cenzus majątkowy. Celem tego postanowienia było wykluczenie od udziału w głosowaniu osób, które zalegały z płaceniem obciążających je podatków (co w pewnym sensie również stanowiło ograniczenie zasady powszechności, choć trudno uznać je za dyskryminujące). Nie można wykluczyć, że przy tak nieprecyzyjnym sformułowaniu użytym w konstytucji mogłoby dojść do uchwalenia ustawy, która wprowadziłaby cenzus majątkowy oparty na kwotach opłacanych podatków i w rezultacie w znaczny sposób przyczyniłaby się do pozbawienia prawa głosu wyborców niższych warstw społecznych. Ralf Kuykendall podaje, że w miejscu

${ }^{11}$ Constitution Granted by His Majesty Kamehameha III, King of the Hawaiian Islands, by and with the Advice and Consent of the Nobles and Representatives of the People in Legislative Council Assembled, June 14 ${ }^{\text {th }}, 1852$, [Lydecker 1918: 36-48]; zob. też: http://hooilina.org/collect/ journal/index/assoc/HASH01ce.dir/5.pdf (dostęp 1.03.2019). 
głosowania wyborca musiał okazać zaświadczenie, z którego wynikało, że opłaca ciążące na nim podatki [1967: 282-283].

Zgodnie z art. 77 drugiej hawajskiej ustawy zasadniczej bierne prawo wyborcze posiadali mężczyźni, który ukończyli 25 lat, potrafili czytać i pisać, rozumieli rachunki oraz przebywali w Królestwie Hawajów co najmniej jeden rok bezpośrednio poprzedzający wybory. Nie mogły kandydować osoby chore psychicznie (insane) lub ograniczone umysłowo (dosłownie: idiots) oraz takie, które w każdej chwili mogły zostać skazane za jakąkolwiek niesławną zbrodnię (sformułowanie to nie jest jasne; naszym zdaniem chodziło o wyłączenie osób, przeciwko którym toczyło się postępowanie karne).

Z omawianych wyżej przepisów (art. 77 i 78) wynikały także przesłanki pozbawienia czynnego i biernego prawa wyborczego. Prawa te nie przysługiwały chorym psychicznie (ustrojodawca posłużył się wieloznacznym określeniem - insane) oraz osobom, które zostały skazane za hańbiące przestępstwo - convicted of any infamous crime. Postanowienie to nie miało zastosowania wobec tych, którzy zostali ułaskawieni przez monarchę i odzyskali wszelkie prawa obywatelskie.

Wybory miały być przeprowadzane z zachowaniem zasady równości formalnej (wyborca miał prawo do jednego głosu w okręgu, w którym przebywał przez trzy miesiące poprzedzające dzień wyborów - art. 78 konstytucji z 1852 r.) oraz materialnej (mandaty miały zostać rozdzielone w zależności od liczby mieszkańców, która miała zostać ustalona podczas urzędowego spisu ludności przeprowadzanego co sześć lat - art. 76). Wyraźne wskazanie w ustawie zasadniczej, że wyborca dysponuje jednym tylko głosem ${ }^{12}$, co powinno było przesądzać sposób głosowania w także w dwumandatowym (później czteromandatowym) okręgu w Honolulu. Gdyby rzeczywiście w takim okręgu głosujący mógł wskazać tylko jednego kandydata, zdecydowanie łagodziłoby to większościowy charakter wyborów, w praktyce uniemożliwiając partii większościowej zdobycie wszystkich mandatów. W praktyce jednak przyjmowano, że wyborca może oddać tyle głosów, ile mandatów obsadzanych jest w danym okręgu; w 1859 roku reguła ta znalazła potwierdzenie w przepisach ustawy.

\section{ZMIANY PRAWA WYBORCZEGO W LATACH 1852-1864}

Rok po uchwaleniu drugiej hawajskiej konstytucji zwiększono liczbę deputowanych, jednocześnie zmieniając strukturę okręgów wyborczych. W Honolulu wybierano odtąd czterech deputowanych (w jednym okręgu), a w okręgach

${ }^{12}$ Every male subject [...] shall be entitled to one vote for the representative or representatives. 
Hilo, Lahaina i Molokai-Lanai - po dwóch ${ }^{13}$. Kolejna istotna zmiana podziału na okręgi wyborcze nastąpiła dopiero po obaleniu monarchii, na mocy republikańskiej konstytucji z 1894 roku [Schmitt 1971: 51]. Ustawą z 30 maja 1856 roku wydłużono kadencję reprezentantów stanowiąc, że będą odtąd wybierani co dwa lata ${ }^{14}$.

Źródłem prawa wyborczego był również kodeks cywilny uchwalony w 1859 roku. Włączono doń przepisy z różnych dziedzin prawa, w tym dotyczące izb parlamentu i zasad wybierania deputowanych (zebrano je w tytule 3. - Of the Legislative Department) ${ }^{15}$. W większości stanowiły one powtórzenie (choć niedosłowne) norm $z$ dotychczas obowiązujących aktów, ale znajdujemy wśród nich także przepisy nowe. W sekcji 778 powtórzono rozwiązania dotyczące prawa wybieralności, przy czym wyliczono przestępstwa, w przypadku których oskarżenie kandydata wyłączało możliwość wyboru. Wprowadzenie tego katalogu nie było zasadne, gdyż jednocześnie dodano, iż utratą biernego prawa wyborczego skutkowało również oskarżenie o każdą inną poważną zbrodnię lub występek. Przepisy o czynnym prawie wyborczym nie zostały istotnie zmienione; dodano wyraźne wskazanie, że nienaturalizowany cudzoziemiec (alien) nie może głosować (sekcja 784).

Pewne zmiany wprowadzono również do przepisów określających przebieg wyborów. Upoważniono ministra spraw wewnętrznych do wyznaczenia w okręgu drugiego miejsca oddawania głosów (sekcja 782). Jego obowiązkiem było zapewnienie zamykanych urn wyborczych (sekcja 786). Wskazując organy administracji wyborczej wymieniono nie inspektorów szkolnych (jak w akcie z 1850 r.), ale urzędnika zwanego School-Superintendent. Wskazano też, że prowadząca wybory Board of Inspectors miała składać się z trzech urzędników (sekcja 785). Wprowadzono przepis przeciwdziałający oddaniu przez jedną osobę więcej niż jednego głosu. Otrzymawszy kartę inspektor wyborczy sprawdzić miał, czy wyborca nie podjął próby dołączenia dodatkowej karty (sekcja 788) ${ }^{16}$,

${ }^{13}$ An act to regulate the number of the representatives of the people. Approved May $26^{\text {th }}$, 1853, [w:] Laws of His Majesty Kamehameha III., King of the Hawaiian Islands, passed by the Nobles and Representatives at their session; 1853, Honolulu 1853, s. 24-25.

${ }^{14}$ An act to amend an act to regulate the elections of representatives of the people passed in 1850, [w:] Laws of His Majesty Kamehameha IV, King of the Hawaiian Islands, passed by the Nobles and Representatives at their session, 1856, Honolulu 1856, s. 19.

${ }_{15}$ The civil code of the Hawaiian Islands, passed in the year of our Lord 1859: to which is added an appendix, containing laws not expressly repealed by the civil code; the session laws of 1858-9; and treaties with foreign nations, Honolulu 1859, ss. 554.

16 Przyjęta procedura, w której głosujący wręczał przyniesioną kartę członkowi komisji, a ten oglądał ją, by sprawdzić, że podjęto próby oddania większej liczby kart, nie pozwalała na zachowanie tajności głosowania. Pamiętać przy tym trzeba, że hawajskie prawo wyborcze nie gwarantowało tej zasady wyborczej. 
wskazano też, że odnalezienie w urnie kart razem zwiniętych lub złączonych skutkować miało ich unieważnieniem (sekcja 794).

Po policzeniu głosów komisja miała ogłosić bardziej szczegółowe wyniki - nie, jak wcześniej, wskazać, kto zdobył najwięcej głosów, ale podać należało liczbę oddanych głosów - w sumie oraz na poszczególnych kandydatów (sekcja 790).

W kodeksie odnajdujemy również przepis, z którego wynikał sposób oddawania głosów w okręgach wielomandatowych. Jeżeli liczba nazwisk wskazanych na karcie przekraczała liczbę reprezentantów wybieranych w danym okręgu - głosy na takiej karcie uznawano za nieważne. Wskazanie mniejszej liczby kandydatów nie wpływało na ważność głosów (sekcja 795). Pojawia się pytanie o zgodność przywołanego przepisu z art. 78 konstytucji z 1852 roku, w którym zapisano, że wyborca oddawał jeden głos. Analizowana norma może być uznana za zgodną z ustawą zasadniczą, o ile przyjmiemy, że one vote, o którym mowa w konstytucji, to jedna karta do głosowania, na której w okręgu wielomandatowym mogło być wskazanych kilka nazwisk.

Co do dość niezwykłe, w kodeksie cywilnym znalazły się rozwinięte i uszczegółowione przepisy karne chroniące prawidłowość przebiegu wyborów (sekcja 800-813). Kodeks z 1859 roku zawierał zatem w sobie nową ordynację wyborczą, opartą na poprzedniej (z 1850 r.), ale posiadającą szereg przepisów nowych lub przeredagowanych.

Poważne zmiany prawa wyborczego przyniosła ustawa zasadnicza z 20 sierpnia $1864 \mathrm{roku}^{17}$, wprowadzona przez Kamehamehę V z pogwałceniem obowiązującej wówczas konstytucji z 1852 roku [Allen 1982: 112, 138; Kuykendall, Grove Day 1976: 112-113; Kuykendall 1940: 27, 36; Haley 2014: 194; McKenzie 1991: 11; Chambers 1896: 20]. Omawianie przyjętych wówczas rozwiązań wykraczałoby poza przyjęte ramy opracowania, ograniczamy się zatem do zasygnalizowania kluczowych kwestii. Parlament stał się jednoizbowym Zgromadzeniem Ustawodawczym, w którym - zgodnie z art. 45 - zasiadali wyznaczeni przez władcę Nobles oraz pochodzący z wyborów Representatives of the People.

Posiadanie prawa głosu uzależniono wówczas od wysokiego cenzusu majątkowego, to jest własności nieruchomości o odpowiedniej wartości, dzierżawy nieruchomości przy odpowiednio wysokim czynszu albo określonego rocznego dochodu. W przypadku prawa wybieralności także obowiązywały kryteria majątkowe, przy czym wskazane kwoty wartości nieruchomości lub rocznych dochodów były kilkakrotnie wyższe niż w przypadku czynnego prawa wyborczego (art. 62). Przyjęte wówczas rozwiązania odsuwały od wyborów znaczną

${ }^{17}$ Constitution Granted by His Majesty Kamehameha V, by the Grace of God, King of the Hawaiian Islands, on the Twentieth Day of August, A. D. 1864, [Lydecker 1918: 88-98]; zob. też: http://hooilina.org/collect/journal/index/assoc/HASHe7d7.dir/5.pdf (dostęp 1.03.2019). 
część rdzennej ludności archipelagu [Allen 1982: 112, 138; Haley 2014: 194; Kuykendall, Grove Day 1976: 113; Kukendall 1940: 39-40; Kukendall 1967: 282-283; Chambers 1896: 21].

\section{HAWAJSKIE WYBORY W PRAKTYCE}

Omawiane przepisy wprowadzono w społeczeństwie, dla którego członków stanowiły one oczywistą nowość. Jeszcze na początku XIX wieku ustrój społeczny Hawajów przypominał europejski feudalizm, nie posługiwano się pismem, nie istniały szkoły, religia tubylców dopuszczała wielożeństwo, składanie ofiar z ludzi, zaś życie wyspiarzy krępowały surowe reguły systemu kapu. W wyniku kontaktów z białymi przybyszami, a zwłaszcza protestanckimi misjonarzami przybywającymi od początku lat 20., nastąpiły gwałtowne przemiany mentalności oraz organizacji społeczeństwa. Hawajczycy przyjęli chrześcijaństwo, szybko rozwijało się szkolnictwo, system opieki zdrowotnej, poczta; działał teatr i wydawano gazety. Bez upowszechnienia pisma i stworzenia aparatu państwowego trudno wyobrazić sobie wybory deputowanych [Szczerbowski 2014: 110-117, 298; Kuykendall, Grove Day 1976: 11, 29, 40-46, 56-62, 76-79, 84-86, 101; Haley 2014: 25, 35, 61-71, 83-105, 121-126, 139, 155-158; Siler 2012: XIII, XIX, 3-6, 9; Daws 1968: 53-65, 80-81, 90-109, 124-132; 2006: 24, 29-31, 62, 134-135, 151-156, 231, 255; Alexander 1891: 48-53; 188-189, 252-264; Sai 2008: 58-61,79-85; Kamakau 1992: 224; McKenzie 1991: 6-9, 149-154].

Na temat frekwencji wyborczej zachowały się jedynie szczątkowe dane, które zebrał Robert C. Schmitt. Z okresu monarchii nie ma zestawień wskazujących na liczby osób uczestniczących w wyborach na terenie całego kraju. Nawet w wydawanych zwycięzcom certyfikatach nie podawano liczby otrzymanych przez nich głosów. Zachowane informacje (w szczególności prasowe) pozwalają jednak na sformułowanie tezy, że w badanym okresie wybory posłów cieszyły się umiarkowanym zainteresowaniem Hawajczyków. Podczas wyborów z 1851 roku (pierwszych przeprowadzonych według nowej ordynacji) w stołecznym Honolulu głosowało 13,9\% populacji, rok później - 8,7\%, a w kolejnych wyborach już tylko 7,2\%. Rekordowo wysoki wynik zanotowano w 1862 roku - 20,9\% (później, po wprowadzeniu cenzusu majątkowego, wskaźnik ten, z oczywistych przyczyn, był znacznie niższy, przed 1897 roku głosowało zaledwie od 1 do 3\% mieszkańców miasta). Niskie zainteresowanie udziałem w wyłanianiu reprezentantów tłumaczono różnie - epidemią ospy (1853 r.) lub sztormową pogodą (1855 r.) [Schmitt 1971: 50-53]. Pamiętać jednak trzeba, że uprawnieni do głosu byli tylko dorośli mężczyźni, a większość 
społeczeństwa stanowiły kobiety i dzieci (dzietność nie była jednak wówczas wysoka, gdyż liczba rdzennej ludności spadała).

Ralf Kuykendall informuje o nadużyciach, jakie zdarzały się w związku z głosowaniem. Po 1852 roku, gdy warunkiem udziału w głosowaniu było przedstawienie zaświadczenia o braku zaległości podatkowych, zdarzało się, że kandydaci i ich pomocnicy odbierali zaświadczenia od tubylców, obiecując ich bezpiecznie przechowanie. W rzeczywistości chodziło o zyskanie kontroli nad ich głosami. W czasie kampanii wyborczej zdarzały się przypadki kupowania poparcia oraz rozdawanie wyborcom alkoholu [1967: 282-283].

Do reformy wyborczej z 1850 roku mandaty poselskie zdobywali rdzenni Hawajczycy, co wynika z zestawień składu legislatury w kolejnych kadencjach. Warto to podkreślić, bowiem już w tym okresie większość kluczowych funkcji w administracji pełnili biali doradcy panującego. W latach 50. sytuacja zaczęła się zmieniać - do parlamentu zaczęli być wybierani również cudzoziemcy, których udział zdecydowanie wzrósł po wprowadzeniu cenzusu majątkowego [Lydecker 1918: 18-35; Kuykendall 1938: 228; Alexander 1891: 229-230; Chambers 1896: 15].

\section{UWAGI KOŃCOWE}

W hawajskiej monarchii następował szybki rozwój instytucji ustrojowych, który był oczywistym rezultatem intensywnych kontaktów z białymi przybyszami, zwłaszcza z USA i Wielkiej Brytanii. Od cudzoziemskich doradców kierujące państwem elity czerpały wiedzę na temat funkcjonujących w świecie modeli organizacji państwa, w których kluczową rolę odgrywał parlament, z przedstawicielami narodu wyłanianymi w wyborach. Podkreślić trzeba, że Hawajczycy nie poszli drogą bezrefleksyjnego kopiowania rozwiązań obcych, ale tworzyli własne, próbując adaptować do lokalnych warunków rozwiązania stosowane w innych krajach.

Świetnym przykładem takiego podejścia jest wczesne prawo wyborcze. Edykt z 1840 roku był regulacją wyraźnie nieporadną, fragmentaryczną, za to oryginalną - hawajską. Stworzono dość niezwykłą procedurę wyłaniania posłów na podstawie listów wysyłanych do władcy, przy czym nie określono ani tego, kto mógł głosować, ani jakie były warunki objęcia mandatu. Kluczowe dla wyborów kwestie musiały być zatem rozstrzygane w praktyce.

Przepisy ustaw z 1850 roku oraz konstytucji z 1852 roku w znacznie większym stopniu przypominały akty znane z innych państw. Podkreślić przy tym należy, że do ustawy zasadniczej z 1864 roku prawo głosu było powszechne (choć tylko dla mężczyzn), a prawo wybieralności także nie było ograniczone 
cenzusem majątkowym. W połowie stulecia powszechność wyborów była wyjątkiem w skali świata, a Królestwo Hawajów stanęło w jednym szeregu z Francją (po 1848 r.).

\section{BIBLIOGRAFIA}

Alexander William DeWitt. 1891. A brief history of the Hawaiian people. American Book Company, Hawaii.

Allen Helena G. 1982. The Betrayal of Liliuokalani Last Queen of Hawaii 1838-1917. Honolulu: A.H. Clark Company.

Chambers Henry Edward. 1896. Constitutional history of Hawaii. Baltimore.

Daws Gavan. 2006. Honolulu. The First Century. The Story of the Town to 1876. Hawaii Honolulu: Mutual Publishing Co.

Daws Gavan. 1968. Shoal of time. A history of the Hawaiian Islands. Honolulu: University of Hawaii Press.

Haley James L. 2014. Captive Paradise a History of Hawaii. New York: St. Martin's Press.

Kamakau Samuel Manaiakalani. 1992. Ruling Chiefs of Hawaii. Honolulu: Kamehameha Schools Press .

Kobus Klaudia. 2017. Ustrój Królestwa Hawajów w świetle dziewiętnastowiecznych konstytucji Łódź (praca magisterska, Uniwersytet Łódzki), Łódź.

Kuykendall Ralph Simpson. 1940. Constitutions of the Hawaiian Kingdom. Honolulu: University of Hawaii.

Kuykendall Ralph Simpson. 1938. The Hawaiian Kingdom. Vol. I, 1778-1854. Foundation and Transformation, Honolulu: University of Hawaii.

Kuykendall Ralph Simpson.1953. The Hawaiian Kingdom. Vol. II, 1854-1874. Twenty Critical Years. Honolulu: University of Hawaii Press.

Kuykendall Ralph Simpson. 1967. The Hawaiian Kingdom. Vol. III: 1874-1893. The Kalakaua Dynasty. Honolulu: University of Hawaii Press.

Kuykendall Ralph Simpson, Grove Day A. 1976. Hawaii: A history. From Polynesian Kingdom to American Statehood New York: Prentice Hall.

McKenzie Melody Kapilialoha (ed.). 1991. Native Hawaiian rights handbook. Honolulu: Native Hawaiian Legal Corporation.

Sai David Keanu. 2008. The American occupation of the Hawaiian Kingdom: beginning the transition from occupied to restored state, Honolulu (rozprawa doktorska, University of Hawai'i); www.hawaiiankindom.org/pdf/Dissertation(Sai).pdf (dostęp 22.04.2018).

Schmitt Robert C. 1971. „Voter Participation Rates in Hawaii Before 1900”. Hawaiian Journal of History" 50, s. 50-58.

Siler Julia Flynn. 2012. Lost Kingdom. Hawaii's Last Queen, the Sugar Kings and America's First Imperial Adventure. New York: Atlantic Monthly Press.

Szczerbowski Tadeusz. 2014. Kultura hawajska. Ka Mo’omeheu Hawai’i. Kraków: Wydawnictwo Naukowe Uniwersytetu Pedagogicznego.

\section{AKTY PRAWNE}

The first constitution of Hawaii, [w:] Robert C. Lydecker (ed.), Roster Legislatures of Hawaii 1841-1918. Constitutions of Monarchy and Republic. Speeches of Sovereigns and President, 
Honolulu 1918, s. 8-15; http://hooilina.org/collect/journal/index/assoc/HASH0166.dir/5.pdf (dostęp 1.03.2019).

Of the Representative Body - Laws of the Hawaiian Islands - Chapter II [edykt z 2.11.1840],

[w:] Translation of the constitution and laws of the Hawaiian Islands, established in the reign of Kamehameha III, Lahainaluna 1842.

An act to regulate the election of representatives of the people, 30.07.1850, [w:] Penal code of the Hawaiian Islands, passed by the House of Nobles and Representatives on the $21^{\text {st }}$ of June, A. D. 1850; to which are appended the other acts passed by the House of Nobles and Representatives during their general session for 1850, Honolulu 1850.

An act to increase the number of the representatives of the people in the Legislative Council, 30.07.1850, [w:] Penal code of the Hawaiian Islands, passed by the House of Nobles and Representatives on the $21^{\text {st }}$ of June, A. D. 1850; to which are appended the other acts passed by the House of Nobles and Representatives during their general session for 1850, Honolulu 1850.

Constitution Granted by His Majesty Kamehameha III, King of the Hawaiian Islands, by and with the Advice and Consent of the Nobles and Representatives of the People in Legislative Council Assembled, June 14 $4^{\text {th }}$ 1852, [w:] Robert C. Lydecker (ed.), Roster Legislatures of Hawaii 1841-1918. Constitutions of Monarchy and Republic. Speeches of Sovereigns nad President, Honolulu 1918, s. 36-48; http://hooilina.org/collect/journal/index/assoc/HASH01ce.dir/5.pdf (dostęp 1.03.2019).

An act to regulate the number of the representatives of the people. Approved May 26 ${ }^{\mathrm{th}}, 1853$, [w:] Laws of His Majesty Kamehameha III., King of the Hawaiian Islands, passed by the Nobles and Representatives at their session; 1853, Honolulu 1853.

An act to amend an act to regulate the elections of representatives of the people passed in 1850, [w:] Laws of His Majesty Kamehameha IV, King of the Hawaiian Islands, passed by the Nobles and Representatives at their session, 1856, Honolulu 1856.

The civil code of the Hawaiian Islands, passed in the year of our Lord 1859: to which is added an appendix, containing laws not expressly repealed by the civil code; the session laws of 1858-9; and treaties with foreign nations, Honolulu 1859.

Constitution Granted by His Majesty Kamehameha V, by the Grace of God, King of the Hawaiian Islands, on the Twentieth Day of August, A. D. 1864, [w:] Robert C. Lydecker (ed.), Roster Legislatures of Hawaii 1841-1918. Constitutions of Monarchy and Republic. Speeches of Sovereigns and President, Honolulu 1918, s. 88-98; http://hooilina.org/collect/journal/index/ assoc/HASHe7d7.dir/5.pdf (dostęp 1.03.2019).

\section{Streszczenie}

Dzieje Królestwa Hawajów (1810-1893) to historia szybkiej modernizacji i westernizacji społeczeństwa wysp, w tym jego systemu prawnego. Hawajskie prawo wyborcze rozwijało się od 1840 r., to jest od ustanowienia wybieralnej Izby Reprezentantów. Wydany wtedy edykt stanowił mało precyzyjną regulację zasad wyłaniania deputowanych, na których głosowano wysyłając listy do władcy. Ustawa wyborcza z 1850 r. okazała się aktem znacznie bardziej nowoczesnym. Podkreślić przy tym należy, że prawo głosu było wówczas powszechne (choć tylko dla mężczyzn). W artykule przedstawiono hawajskie ustawodawstwo wyborcze do reformy przeprowadzonej w 1864 r., gdy nowa ustawa zasadnicza przyniosła istotne zmiany. 
Słowa kluczowe: prawo wyborcze, Królestwo Hawajów, historia ustroju Hawajów.

\section{HAWAIIAN ELECTORAL LEGISLATION IN THE YEARS 1840-1864 (summary)}

The history of the Kingdom of Hawaii (1810-1893) is a story of the rapid modernization and westernization of the island society, including its legal system. Hawaiian electoral law existed since 1840, when The House of Representatives with elective members was established by the first constitution. The edict issued then was an imprecise, even primitive, regulation of the rules of electing deputies. People entitled to vote voted by sending letters to the monarch. The electoral act of 1850 can be regarded as much more modern one. It should be emphasized that at that time the right to vote was universal (though only for male citizens). The article presents the Hawaiian electoral legislation till the reform of 1864 , when important changes took place.

Keywords: electoral law, the Kingdom of Hawaii, Hawaiian constitutional history. 